\title{
How does tobacco growing impact advancement in demand reduction measures?
}

\author{
Raphael Lencucha', Jeffrey Drope ${ }^{2}$
}

Tobacco consumption remains a dire global health issue and the tobacco industry continues to find nefarious ways of keeping demand and consumption high. In the background lies the challenging, and often neglected, issue of tobacco growing and supply. Tobacco growing has proven to be a problematic practice due to its detrimental environmental impact ${ }^{1}$, the deeply troubling health implications of growing and processing ${ }^{2}$, and the precarious economic livelihoods of most farming households $\mathrm{s}^{3-5}$. What requires particular attention is the critical relationship between tobacco supply (e.g. growing, processing, and manufacturing) and demand reduction measures. Here, we provide a glimpse into the ways that tobacco growing affects the ability of governments to institute demand reduction measures in tobacco growing countries.

Many governments and other stakeholders in tobacco growing countries believe that commercial tobacco cultivation, particularly among small family-run farms, presents a path to macro- and micro-economic prosperity. On a macrolevel, governments particularly value the export and foreign exchange potential and the perceived contribution to employment. Tobacco can generate significant exports and foreign exchange, but the reward calculus tends to be superficial, overlooking the costs to farming households and the environment.

Tobacco cultivation does employ thousands of farmers in some countries, but governments (and especially industry) typically oversimplify the nature of this employment. First, in most countries where researchers have rigorously measured livelihoods, many - often most - farmers consistently lose money cultivating tobacco ${ }^{4-8}$. Second, tobacco is typically only part, and sometimes a small part, of a farmer's crop portfolio and research demonstrates that many other crops and/or off-farm economic activities generate greater household resources ${ }^{9}$. The labour demands of tobacco are also great, with widespread use of child labor ${ }^{10}$. Third, tobacco farming causes Green Tobacco Sickness, a form of acute nicotine poisoning, among many who handle the leaf ${ }^{11}$. Fourth, the chemical overuse and deforestation from growing and curing tobacco devastate ecosystems and thereby the long-term health and economic prosperity of entire communities ${ }^{6,12}$. Put simply, if farmers reallocated their labor, land and/ or precious capital to other activities, it is likely that overall employment would increase and farmers' livelihoods and communities would improve.

The misguided beliefs about the economic potential of tobacco growing have prompted governments to enact policies that encourage tobacco growing. By encouraging greater production, these policies typically drive down the costs and prices of tobacco thereby increasing consumption and motivating powerful actors to undermine tobacco control efforts. For example, in the latest Seventh National Development Plan, 2017-21, Zambia's government included tobacco growing as a priority crop, stating that tobacco 'has great potential to contribute

AFFILIATION

1 School of Physical \& Occupational Therapy, Faculty of Medicine and Health Sciences, McGill University, Montreal, Canada 2 School of Public Health, University of Illinois at Chicago, Chicago, United States

\section{CORRESPONDENCE TO}

Raphael Lencucha. School of Physical \& Occupational Therapy, Faculty of Medicine and Health Sciences, McGill University, Montreal, Quebec H3A 0G4, Canada. E-mail: raphael.lencucha@ megill.ca

\section{KEYWORDS}

tobacco growing, tobacco farming, tobacco control, tobacco supply, public policy, governance

Received: 18 January 2020 Accepted: 20 January 2020 
to the growth of the economy through employment and wealth' (p. 146,11) ${ }^{13}$. There are detailed plans to support the production of tobacco growing and processing. In North Macedonia, tobacco is the most heavily subsidized crop even though the rewards of these subsidies appear to accrue mainly to the tobacco companies that buy the leaf. A recent World Bank report states unequivocally: 'Farm support does not improve efficiency and productivity and has a very low impact on poverty reduction' ${ }^{14}$. In Argentina, the significant revenue raised by the Special Tobacco Fund (Spanish acronym: FET) on cigarettes is reallocated back to the tobacco-growing provinces, which motivates the powerful subnational governments to oppose any tobacco control measures that might mitigate consumption ${ }^{15}$.

This policy and institutional context enhances the power of the tobacco industry in tobacco growing countries. This power is expressed in two ways. The first expression of power is through direct and indirect involvement with government institutions that govern the tobacco market. It is common for tobacco industry representatives to sit on boards that dictate the price and processes of tobacco leaf sales ${ }^{16}$. This involvement situates formal decision-making power with these representatives. This involvement also indirectly exerts influence within government by influencing norms, such as the primacy of perceived economic goals as opposed to health goals, in tobacco policy, thus positioning tobacco as an economic commodity of sustained importance ${ }^{17,18}$. The other expression of power is through industry control of the supply chain. Tobacco farming has come under increasing control of leaf buying companies in the form of direct contractual relationships with farmers. Governments leave companies to manage the supply chain with little or no oversight. For example, in Kenya, tobacco is listed as an 'unscheduled' crop ${ }^{19}$, meaning that extension services and other supports to farmers common to other crops are not provided by government ${ }^{20}$. Contracts typically include the provision of loans and agricultural inputs like seeds and fertilizer for tobacco growing, and purports to guarantee a buyer at harvest time. This type of industry power affects demand reduction by harnessing the political support of farmers in opposition to tobacco control policies. The most pronounced example of this is the work of the International Tobacco Growers Association, a body that coordinates and mobilizes national branches of the organization to ostensibly channel the interests of tobacco farmers in policy contexts $^{21}$. Despite mounting evidence discrediting the narrative that tobacco farming is a lucrative economic activity, this narrative continues to be applied and adopted by government officials both domestically and in international forums ${ }^{17,22}$.

The dynamics discussed above create an institutional environment that produces challenges for health ministries to institute comprehensive tobacco control measures. To begin, the suffusion of industry interests within government shapes the ways that these interests are handled and viewed by the economic sector. For example, the Philippines, Brazil and a number of other countries, that have established intersectoral tobacco control boards in accordance with Article 5.2 of the FCTC, have either overtly included industry representatives or have indirectly included these interests through consultation $^{23-25}$. The decisions to include these interests are justified with reference to dominant economic norms that view industry as a legitimate stakeholder in government decision-making ${ }^{26}$. Health ministries must contend with these entrenched norms and their manifestation through the inclusion of industry interests. In Zambia, significant delays in adopting FCTC compliant tobacco control legislation have been attributed to the presence of tobacco growing and related interests ${ }^{27}$. Comprehensive tobacco control measures require participation and support across government sectors including agriculture, labour, trade and industry, and when these sectoral mandates are supportive of tobacco as an economic commodity, intractable conflicts emerge that undermine healthfocused tobacco control efforts.

The most consequential supply-based threat to tobacco control is the political power that tobacco growing gives the tobacco industry, and the closely-related institutional entrenchment of tobacco interests within government. The industry continues to successfully promote the supposed threat from tobacco control to farmers' livelihoods and/or the broader economy as a reason not to enact stronger policies such as higher excise taxes on these products. Yet, these claims are contradicted 
by a growing body of evidence that demonstrates that the micro- and macro-economic contributions of tobacco are not only significantly less important than the industry claims but, in many cases, may be fundamentally undermining governments' economic development efforts.

\section{REFERENCES}

1. Lecours N. The Harsh Realities of Tobacco Farming: A Review of Socioeconomic, Health and Environmental Impacts. In: Tobacco control and tobacco farming: Separating myth from reality. Ottawa, ON: Anthem Press (IDRC); 2014.

2. Leppan W, Lecours N, Buckles D. Tobacco control and tobacco farming: Separating myth from reality. Ottawa, ON: Anthem Press (IDRC); 2014.

3. Chingosho R, Dare C, van Walbeek C. Tobacco farming and current debt status among smallholder farmers in Manicaland province in Zimbabwe. Tob Control. 2020. doi:10.1136/tobaccocontrol-2020-055825

4. Magati P, Lencucha R, Li Q, et al. Costs, contracts and the narrative of prosperity: an economic analysis of smallholder tobacco farming livelihoods in Kenya. Tob Control. 2019;28(3):268273. doi:10.1136/tobaccocontrol-2017-054213

5. Makoka D, Drope J, Appau A, et al. Costs, revenues and profits: an economic analysis of smallholder tobacco farmer livelihoods in Malawi. Tob Control. 2017;26(6):634-640. doi:10.1136/tobaccocontrol-2016-053022

6. Hussain AG, Rouf ASS, Shimul SN, et al. The Economic Cost of Tobacco Farming in Bangladesh. Int J Environ Res Public Health. 2020;17(24):9447. doi:10.3390/ijerph17249447

7. Sahadewo GA, Drope J, Li Q, Nargis N, Witoelar F. Tobacco or not tobacco: predicting farming households' income in Indonesia. Tob Control. 2020. doi:10.1136/tobaccocontrol-2019-055274

8. Talukder A, Haq I, Ali M, Drope J. Factors Associated with Cultivation of Tobacco in Bangladesh: A Multilevel Modelling Approach. Int J Environ Res Public Health. 2020;17(12):4277. doi:10.3390/ijerph17124277

9. Sahadewo GA, Drope J, Witoelar F, Li Q, Lencucha R. The Economics of Tobacco Farming in Indonesia: Results from Two Waves of a Farm-Level Survey. Chicago, IL: University of Illinois at Chicago; 2020.

10. Human Rights Watch. The Harvest is in My Blood: Hazardous Child Labor in Tobacco Farming in Indonesia. Human Rights Watch; 2016. https://www.hrw.org/sites/ default/files/report_pdf/indonesia0516_brochure_web. pdf. Accessed January 18, 2021.

11. McKnight RH, Spiller HA. Green Tobacco Sickness in Children and Adolescents. Public Health Rep. 2005;120(6):602-605. doi:10.1177/003335490512000607

12. Mangora MM. Shifting Cultivation, Wood Use and Deforestation Attributes of Tobacco Farming in Urambo District, Tanzania. Current Research Journal of Social
Sciences. 2012;4(2):135-140. http://repository.udsm. ac.tz:8080/xmlui/bitstream/handle/20.500.11810/1726/ Shifting\%20Cultivation $\% 2$ c\%20Wood $\% 20$ Use $\% 20$ and $\% 20$ Deforestation \%20Attributes\%20 of \%20Tobacco $\% 20$ Farming.pdf? sequence $=1 \&$ is Allowed $=y$. Accessed January 18, 2021.

13. Zambia Ministry of National Development Planning. Seventh National Development Plan 2017-2021: Accelerating development efforts towards vision 2030 without leaving anyone behind. Lusak, Zambia: Ministry of National Development Planning; 2017:166.

14. World Bank. North Macedonia Special Focus Note: Agriculture. World Bank Group; 2018. http://documents1. worldbank.org/curated/en/540801560754049765/pdf/ North-Macedonia-Special-Focus-Note-Agriculture.pdf. Accessed January 12, 2021.

15. González-Rozada M. Impact of a recent tobacco tax reform in Argentina. Tob Control. 2020;29(Suppl 5):s300-s303. doi:10.1136/tobaccocontrol-2019-055238

16. Smith J, Lee K. From colonisation to globalisation: a history of state capture by the tobacco industry in Malawi. Rev Afr Polit Econ. 2018;45(156):186-202. doi:10.1080/03056244.2018.1431213

17. Lencucha R, Reddy SK, Labonte R, et al. Global tobacco control and economic norms: an analysis of normative commitments in Kenya, Malawi and Zambia. Health Policy Plan. 2018;33(3):420-428. doi:10.1093/heapol/czy005

18. Kulik MC, Bialous SA, Munthali S, Max W. Tobacco growing and the sustainable development goals, Malawi. Bull World Health Organ. 2017;95(5):362. doi:10.2471/BLT.16.175596

19. Republic of Kenya. The Crops Act, 2013. No. 16 of 2013. http://extwprlegs1.fao.org/docs/pdf/ken122138.pdf. Published January 25, 2013. Accessed January 18, 2021.

20. Clark M, Magati P, Drope J, Labonte R, Lencucha R. Understanding Alternatives to Tobacco Production in Kenya: A Qualitative Analysis at the Sub-National Level. Int J Environ Res Public Health. 2020;17(6):2033. doi:10.3390/ijerph17062033

21. Assunta M. Tobacco industry's ITGA fights FCTC implementation in the Uruguay negotiations. Tob Control. 2012;21(6):563-568. doi:10.1136/tobaccocontrol-2011-050222

22. Lencucha R, Drope J, Labonte R. Rhetoric and the law, or the law of rhetoric: How countries oppose novel tobacco control measures at the World Trade Organization. Soc Sci Med. 2016;164:100-107. doi:10.1016/j.socscimed.2016.07.026

23. Lencucha R, Drope J, Aguinaga Bialous S, Richter AP, da Costa e Silva VL. Institutions and the implementation of tobacco control in Brazil. Cad Saúde Pública. 2017;33(Suppl 3):1-11. https://www.scielo.br/pdf/ csp/v33s3/en_1678-4464-csp-33-s3-e00168315.pdf. Accessed January 18, 2021.

24. Lencucha R, Drope J, Chavez JJ. Whole-of-government approaches to NCDs: the case of the Philippines Interagency Committee-Tobacco. Health Policy Plan. 
2015;30(7):844-852. doi:10.1093/heapol/czu085

25. Crosbie E, Sebrié EM, Glantz SA. Tobacco industry success in Costa Rica: the importance of FCTC article 5.3. Salud Pública México. 2012;54(1):28-38. PMID:22286826.

26. Lencucha R, Thow AM. How Neoliberalism Is Shaping the Supply of Unhealthy Commodities and What This Means for NCD Prevention. Int J Health Policy Manag. 2019;8(9):514-520. doi:10.15171/IJHPM.2019.56

27. Labonté R, Lencucha R, Drope J, Packer C, Goma FM, Zulu R. The institutional context of tobacco production in Zambia. Glob Health. 2018;14(1):5. doi:10.1186/s12992-018-0328-y

\section{ACKNOWLEDGEMENTS}

This editorial draws from research supported by the Canadian Institutes of Health Research (PJT166086), National Institutes of Health (OD) and the National Cancer Institute (R01TW010898) and the National Institute on Drug Abuse, the Fogarty International Center and National Cancer Institute (R01DA035158).

\section{CONFLICTS OF INTEREST}

The authors have completed and submitted the ICMJE Form for Disclosure of Potential Conflicts of Interest and none was reported.

FUNDING

There was no source of funding for this research.

PROVENANCE AND PEER REVIEW

Commissioned; internally peer reviewed. 